\title{
PENGARUH PENGGUNAAN MEDIA ANIMASI TERHADAP HASIL BELAJAR BIOLOGI SISWA PADA MATERI POKOK SISTEM REPRODUKSI PADA MANUSIA DI KELAS XI IPA SMA NEGERI 5 BINJAI
}

\author{
KHAIRINA AFNI \\ STKIP Budidaya Binjai \\ Email: khairinaafni89@gmail.com
}

\begin{abstract}
ABSTRAK
Penelitian ini bertujuan untuk mengetahui pengaruh penggunaan media animasi terhadap hasil belajar biologi siswa pada materi pokok sistem reproduksi pada manusia di kelas XI IPA SMA negeri 5 Binjai. Pembelajaran Biologi akan menyenangkan jika disajikan dengan menggunakan media pembelajaran, salah satunya penggunaan media animasi yang dapat membantu untuk meningkatkan pemahaman maupun mencegah terjadinya kesalahpahaman dan kesulitan dalam mempelajari materi pokok sistem reproduksi. Hal inilah yang menjadi sumber penelitian. Oleh karena itu pengaruh penggunaan media animasi terhadap hasil belajar biologi siswa dijadikan salah satu alternatif untuk meningkatkan hasil belajar siswa.. Sampel dalam penelitian ini berjumlah 30 siswa pada kelas ekperimen yang merupakan siswa kelas XI IPA SMA Negeri 5 Binjai. Metode yang digunakan dalam penelitian ini adalah metode eksperimen dengan desain eksperimen pretest-posttest control group desaign. Dari pengolahan data diperoleh nilai rata-rata kelas eksperimen pada hasil pretest $=$ 36,78 dan pada hasil postest $=79,56$. Dari nilai rata-rata tersebut terlihat bahwa rata-rata hasil belajar kelas eksperimen yang diajarkan dengan menggunakan media animasi lebih baik. Hasil perhitungan uji normalitas dan uji homogeniras menunjukkan bahwa data berdistribusi normal dan juga homogen. Berdasarkan hasil uji hipotesis pada data postest dengan menggunakan uji $t$ diperoleh nilai $t_{\text {hitung }}>t_{\text {tabel }}(5,72>2,00)$ dengan melihat hasil tersebut dapat disimpulkan bahwa dalam penelitian ini $\mathrm{H}_{a}$ diterima sekaligus menolak $\mathrm{H}_{0}$ yang berarti terdapat pengaruh penggunaan media animasi terhadap hasil belajar biologi siswa pada materi pokok sistem reproduksi di kelas XI IPA SMA Negeri 5 Binjai.
\end{abstract}

Kata Kunci: Media animasi, hasil belajar biologi, sistem reproduksi 


\section{PENDAHULUAN}

Proses belajar mengajar pada hakekatnya adalah proses komunikasi, yaitu proses penyampaian pesan dari sumber pesan melalui saluran. Pesan berupa isi ajaran dan didikan yang ada dikurikulum dituangkan oleh guru atau sumber lain ke dalam simbol-simbol komunikasi berupa simbol verbal maupun non verbal.Penggunaan media pada tahap awal proses belajar mengajar dapat membangkitkan keinginan dan minat yang baru, membangkitkan motivasi dan rangsangan untuk belajar serta memberikan pengaruh psikologis terhadap siswa. Dengan media kerumitan bahan yang akan disampaikan dapat disederhanakan.

Media mempunyai kelebihan dan kekurangan, sehingga dalam tindakan komunikasi yang berbeda tentu diperlukan media yang berbeda pula. Pembelajaran menggunakan media animasi belum tentu lebih baik dari pembelajaran menggunakan media gambar. Disisi lain Pengg-unaan Media Audio-Visual dinilai lebih efektif dalam keberhasilan belajar siswa. Seperti yang dikemukakan (Marbun, 2010) dalam skripsinya yang berjudul "Perbandingan Hasil Belajar Siswa Yang Menggunakan Multimedia Dengan Media Sederhana Pada
Sub Materi Pokok Sistem Reproduksi di Kelas XI IPA SMA Negeri 1 Percut Sei Tuan" bahwa hasil belajar siswa dengan menggunakan media audio-visual lebih efektif dari pada hasil belajar siswa yang menggunakan media sederhana.

Dalam mempelajari biologi bukan semata-mata hanya menghapal tetapi harus memahami konsep-konsep dasarnya, karena pelajaran biologi serba kompleks dan memerlukan nalar yang tinggi untuk menganalisanya. Salah satu pokok bahasan pelajaran biologi di SMA adalah sistem reproduksi diperlukan pemahaman yang lebih karena topik ini merupakan salah satu pokok bahasan yang konsep dasarnya cukup abstrak sehingga tidak mudah dipahami siswa. Walaupun manusia memiliki sistem reproduksi, namun secara kongkritnya tidak semua hal yang berhubungan dengan sistem reproduksi dapat dilihat. Yang dapat diketahui dan dilihat hanya terbatas pada alat-alat reproduksi luar saja. Untuk itu dengan kehadiran media animasi dan media gambar ini diharapkan akan memberikan pengalaman belajar yang menarik sehingga dapat tersimpan lama dalam memori peserta didik. Berdasarkan hasil observasi dan wawancara dengan guru yang mengajar biologi di SMA Negeri 5 Binjai diperoleh bahwa guru yang bersangkutan menggunakan metode ceramah dalam 
menyampaikan materi pembelajaran, dan kurang didukung dengan media pembelajaran yang lain. Pengajaran dengan ceramah tersebut diketahui bahwa masih rendahnya nilai atau hasil belajar biologi siswa kelas XI IPA SMA Negeri 5 Binjai khususnya pada materi sistem reproduksi manusia. Dimana terdapat lebih dari 50\% siswa mendapat nilai $<60$, dengan kriteria ketuntasan minimal (KKM) sebesar 65.

Berdasarkan fakta tersebut, maka permasalahan yang muncul adalah bagaimana upaya guru dalam meningkatkan hasil belajar siswa pada materi sistem reproduksi manusia, dimana tidak hanya menggunakan metode ceramah tanpa memanfaatkan sarana dan prasarana yang ada di sekolah dalam mengajar, salah satunya dengan menggunakan media animasi dan media gambar. Namun penggunaanya sebagai media pembelajaran masih belum optimal. Ha nya sebagian guru yang dapat me nggunakannya. Hal ini disebabkan masih banyak diantara guru-guru yang kurang paham dalam mengoperasikannya. Disamping itu jumlah LCD proyektor yang tersedia hanya 1 buah, jadi pemakaiannya pun terbatas.Media animasi dapat membantu untuk meningkatkan pemahaman maupun mencegah terjadinya kesalahpahaman dan kesulitan dalam mempelajari materi pokok sistem reproduksi.

Penelitian ini penting dilaksanakan demi meningkatkan hasil belajar siswa pada materi pokok sistem reproduksi manusia, mengingat kesulitan dan kurang pemanfaatan media oleh guru serta hasil belajar siswa yang rendah. Maka penulis tertarik untuk melakukan penelitian tentang:

“ Pengaruh Penggunaan Media Animasi Terhadap Hasil Belajar Biologi Siswa Pada Materi Pokok Sistem Reproduksi Pada Manusia Di Kelas XI IPA SMA Negeri 5 Binjai".

\section{KAJIAN TEORITIS}

\section{A. Pengertian Belajar}

Belajar merupakan masalah yang paling mendasar dan aktual bagi setiap orang. Tanpa belajar seseorang tidak akan dapat menguasai suatu hal. Belajar dapat mencakup semua hal. Semua hal perlu dipelajari bahkan sejak lahir. Maka dari itu banyak ahli-ahli membahas dam menghasilkan teori tentang belajar. Dalam hal ini tidak ada pertentangan mengenai teori yang dihasilkan, tetapi yang penting adalah pemakaian dan aplikasi teori yang digunakan di dunia pendidikan.

Siswa adalah penentu terjadinya atau tidak proses belajar. Berhasil atau gagalnya pencapaian tujuan pendidikan tergantung pada proses belajar dan mengajar 
yang dialami siswa dan pendidik baik ketika para siswa itu di sekolah maupun di lingkungan keluarganya sendiri. Jadi belajar merupakan tindakan dan perilaku siswa yang kompleks, sebagai tindakan belajar hanya dialami oleh siswa itu sendiri (Dimyanti dan Mudjiono, 2002).

\section{B. Pengertian Hasil Belajar}

Hakekat dalam aktivitas belajar adalah suatu perubahan yang terjadi dalam diri masing-masing individu. Perubahan ini nantinya akan mempengaruhi pola pikir individu dalam berbuat dan bertindak. Perubahan ini merupakan hasil dari pengalaman belajar. Hasil belajar dikatakan relatif menetap karena adanya kemungkinan suatu hasil belajar ditiadakan atau dihapuskan dan digantikan dengan hasil yang baru.

Dari uraian tersebut maka dapat dipahami mengenai hasil belajar, yaitu kemampuan yang diperoleh setelah mendapatkan kegiatan belajar yang mengakibatkan perubahan dalam diri individu sebagai hasil dari aktivitas dalam belajar. Program pengajaran dapat dipandang sebagai usaha mengubah tingkah laku siswa dengan mengubah bahan pengajaran. Tingkah laku yang diterapkan itu terjadi setelah siswa mempelajari pelajaran

tersebut.
Hasil belajarnya dapat berupa pengetahuan, keterampilan, dan perubahan sikap. Hasil belajar siswa sangat erat kaitanya dengan tujuan intruksional yang sudah direncanakan guru sebelumnya. Hal ini juga dipengaruhi oleh kemampuan guru sebagai perancang belajar mengajar. Tujuan intruksional dapat dikelompokkan dalam tiga kategori yaitu kognitif, afektif, dan psikomotorik. Dengan demikian tujuan belajar adalah terjadinya perubahan tingkah laku individu yang belajar dimana perubahan perilaku tersebut merupakan perubahan yang bersifat positif. Hasil belajar bergantung pada apa yang dipelajari dan faktor-faktor yang mempengaruhi proses belajar. Karena faktor yang mempengaruhi proses belajar tidak pernah sama, sehingga hasil belajar juga dapat terjadi perbedaan. Seseorang dapat dikatakan memiliki prestasi belajar dalam bidang studi biologi yaitu apabila tujuan yang direncanakan dalam pengajaran tersebut tidak secara kognitif, afektif, dan psikomotorik seperti yang terlihat dalam diri siswa yang mengikuti interaksi belajar mengajar.

\section{Media Dalam Pembelajaran}

\section{Arti Media}

Arti media berasal dari bahasa latin dan merupakan bentuk jamak dari kata medius yang secara harfiah berarti tengah, 
perantara atau pengantar. Media menurut makna umumnya adalah perantara atau pengantar pesan dari pengantar pesan dari pengirim kepenerima pesan. Sedangkan media pembelajaran adalah sarana komunikasi yang digunakan untuk menyampaikan pesan atau bahan pembelajaran. Dengan demikian media pembelajaran adalah media yang dirancang secara khusus untuk merangsang pikiran, perasaan, perhatian dan kemauan peserta didik sehingga terjadinya proses pembelajar an.

Penggunaan media untuk keperluan pembelajaran diawali dengan digunakanya Alat Bantu Visual (AVA) dalam upaya menyajikan pengalaman konkret melalui visualisasi dengan tujuan antara lain untuk memperkenalkan, memperkaya, atau memperjelas konsep yang abstrak dan mendorong timbulnya kegiatan peserta didik lebih lanjut. Dengan penggunaan bahan visual maka suatu konsep yang sifatnya abstrak akan menjadi lebih konkret atau untuk menghindari verbalisme (Warsita,2008).

Media apabila dipahami secara garis besar adalah manusia, materi, atau kejadian yang membangun kondisi yang membuat siswa mampu memperoleh pengetahuan, keterampilan dan sikap. Dalam pengertian ini, guru, buku teks, dan lingkungan sekolah merupakan media. Secara lebih khusus, pengertian media dalam poses belajar mengajar cinderung diartikan sebagai alatalat grafis, photografis, atau elektronis untuk menangkap, memproses dan menyusun kembali informasi visual atau verbal (Gerlach dan Ely dalam Arsyad, 2009).

\section{Peranaaan dan Fungsi Media Pembelajaran}

Media dapat digunakan

dalam kegiatan pembelajaran karena berbagai kemampuannya sebagai berikut :

a. Memperbesar benda yang sangat kecil dan tidak Nampak oleh mata, seperti penggunaan gambar, film perkembangan kuman atau sel.

b. Menyajikan benda atau peristiwa yang terlalu jauh dari peserta didik, misalnya penggunaan gambar atu video tentang air terjun Niagara, bulan, perut bumi dan sebagainya.

c. Menyajikan benda atau peristiwa berbahaya kehadapan peserta didik.

d. Meningkatkan daya tarik pelajaran dan perhatian peserta didik.

e. Meningkatkan sistematika pembelajaran, seperti penggunaan transportasi/OHP, power point, kaset audio dan grafik dalam pembelajaran.

\section{Macam-Macam Media}

Pembelajaran 
Media pembelajaran banyak jenis dan macamnya. Dari yang paling sederhana dan murah hingga yang canggih dan mahal. Ada yang dapat dibuat guru sendiri dan ada yang diproduksi pabrik. Ada yang sudah tersedia dilingkungan untuk langsung dimanfaatkan dan ada yang sengaja dirancang.

Berbagai sudut menggolongkan jenisjenis media. Rudy Bretz (1971) dalam Ariani (2010) menggolongkan media berdasarkan tiga unsur pokok (suara, visual dan gerak) :

1. Media audio

2. Media cetak

3. Media visual diam

4. Media visual gerak

5. Media audio semi gerak

6. Media visual semi gerak

7. Media audio visual diam

Schramm (1985) dalam Ariani (2010) menggolongkan media berdasarkan kompleksnya suara, yaitu : media kompleks (Film, TV, Video/VCD) dan media sederhana (slide, audio, transparansi, teks). Selain itu menggolongkan media berdasarkan jangkauannya, yaitu media masal (liputanya luas dan serantak/kaset audio, video, animasi, OHP dan slide).

\section{Pengertian animasi}

Animasi berasal dari bahasa latin yaitu "anima" yang berarti jiwa, hidup dan semangat. Sedangkan animasi secara utuh diartikan sebagai gambar yang memuat objek yang seolah-olah hidup, disebabkan oleh kumpulan gambar itu berubah beraturan dan bergantian ditampilkan. Objek dalam gambar bisa berupa tulisan, bentuk benda, warna dan spesial efek.

Fitur penting dalam multimedia adalah animasi, dimana animasi dapat berfungsi untuk mengarahkan perhatian peserta didik pada aspek penting dari materi yang sedang dipelajari, menurut Schnotz dan Bannet (2003) dalam Ariani 2010 pemahaman melalui teks dan gambar dapat mendukung pembentukan mental melalui berbagai latar belakang pengetahuan anak sebelumnya. Animasi dapat digunakan untuk menarik perhatian peserta didik jika digunakan secara tepat, tetapi sebaliknya jika animasi juga dapat juga mengalihkan perhatian dari substansi materi yang disampaikan kehiasan animatif yang justru tidak penting. Proses pelajaran kognitif peserta didik dapat dibantu dengan animasi, sedangkan tanpa animasi proses kognitif tidak dapat dilakukan. Peserta didik yang memiliki latar belakang pendidian dan pengetahuan rendah cinderung memerlukan bantuan, salah satunya animasi, untuk menangkap

konsep materi yang disampaikan.

Berdasarkan teknik pembuatannya animasi dibedakan menjadi sepuluh jenis 
yaitu : animasi cel, animasi frame, animasi sprite, animasi path, animasi spline, animasi vektor, animasi clay, morphing, animasi digital dan animasi karak ter.

\section{Kelemahan dan keuntungan media animasi adalah:}

- Keuntungan

Pada umumnya dapat memberikan suasana yang hidup, penampilannya lebih menarik, dan dapat digunakan untuk meperlihatkan suatu proses tertentu secara lebih nyata.

\section{- Kelemahan}

Kelemahan media ini, terutama terletak dalam segi teknis dan juga biaya. Penggunaan media ini memerlukan dukungan sarana dan prasarana tertentu seperti listrik serta peralatan/bahan-bahan khusus yang tidak selamanya mudah diperoleh di temat-tempat tertentu. Di samping itu, pengadaan maupun pemeliharaannya cinderung menuntut biaya yang mahal (Ibrahim dan syaodih, 2003)

\section{Teknik Pengajaran menggunakan}

\section{Media Animasi}

Dalam hal ini terknik pengajaran menggabungkan beberapa media (multimedia) dalam pembuatan CD. Konsep penggabungan ini dengan sendirinya memerlukan beberapa jenis peralatan perangkat keras yang masing-masing tetap menjalankan fungsi utamanya sebagaimana biasanya, dan komputer merupakan pengendali seluruh peralatan itu. Jenis peralatan itu adalah computer lainnya, video kamera, video kaset rekorder (VCR), overhead proyektor, multivision (LCD atau sejenisnya), CD player dan DVD player.

Informasi yang disajikan melalui multimedia berbentuk dokumen yang hidup, dapat dilihat dilayar monitor atau ketika diproyeksikan kelayar lebar melalui overhead proyektor, dan dapat didengar suaranya. Teknik pengajaran yang umum digunakan untuk pengajaran bila dikaitkan dengan media animasi saat ini adalah menggunakan slide Power Point yang biasanya digunakan untuk persentase yang bersifat kontiniu. Dengan membuat tampilan animasi yang dapat ditampilkan secara kontiniu ataupun satu demi satu, dapat membuat penggunaan program Power Point berbasis komputer lebih efisien untuk dipakai sebagai bagian dari teknik pengajaran dengan media animasi.

Multimedia berbasis komputer ini sangat menjanjikan untuk penggunaanya dalam bidang pendidikan. Meskipun saat ini penggunaan media ini masih dianggap mahal, dalam beberapa tahun mendatang biaya itu semakin rendah dan dapat terjangkau sehingga dapat digunakan secara meluas di berbagai jenjang sekolah.

\section{Media Cetak}

Media cetak adalah bahan yang diproyeksikan melalui percetakan 
profesional, seperti buku, gambar, majalah, dan modul. Disamping itu masih ada bahan lain yang juga dapat digolongkan ke dalam istilah cetak seperti gambar/bagan/tulisan. Gambar termasuk media visual, dimana fungsi pokoknya adalah menyajikan ide-ide atu konsep-konsep yang sulit bila disampaikan secara tertulis atau secara visual. Gambar juga mampu memberikan ri ngkasan butir-butir penting dari suatu prese ntasi (Sadiman, 2003).

Menurut Ibrahim (2003) media elektronik saat ini sangat digemari para pendidik sebagai media pelajaran, namun bahan-bahan cetak seperti gambar tidak dapat ditinggalkan sebagai media pengajaran. Bahan media gambar akan selalu memegang peranaan penting dalam pendidikan. Kecenderungan yang ada menunjukkan, di masa yang akan datang media cetak dan media komunikasi akan berbagi tugas dalam melayani kepentingan belajar siswa disekolah. Dengan diperkenalkannya gambar-gambar yang menarik dan dengan dikembangkan proses percetakan yang baru, cepat dan ekonomis.

Ada beberapa keuntungan dan kelemahan dalam penggunaan media cetak/gambar.

\section{a. Keuntungan}

Keuntungan dari media ini, pengadaannya relatif murah dan penggunaannya tidak memerlukan peralatan khusus, serta lebih mudah digunakan , dibawa dan dipindahkan.

b. Kelemahan

Kelemahan dari media ini, terutama jika kurang dirancang dengan baik, cinderung membosankan, tidak dapat memberikan suasana yang hidup dalam kelas.

\section{PENELITIAN RELEVAN}

Menurut (Laura, 2010) saat melakukan penelitian di SMA Negeri 2 Pematang Siantar, ketika dilakukan pembelajaran dengan menggunakan multimedia (audiovisual) dalam bentuk VCD (video compact disc) dengan cara menayangkan langsung VCD pembelajaran di depan kelas, siswa tidak tertarik dan tidak termotivasi untuk belajar.

Hal ini ditunjukkan oleh keadaan $\mathrm{k}$ elas, siswa yang tidak memperhatikan, bahkan mengganggu teman saat proses pem belajaran berlangsung. Disisi lain Penggunaan Media Audio-Visual dinilai lebih efektif dalam keberhasilan belajar siswa. Seperti yang dikemukakan (Marbun, 2010) dalam skripsinya yang berjudul "Perbandingan Hasil Belajar Siswa Yang Menggunakan Multimedia Dengan Media Sederhana Pada Sub Materi Pokok Sistem Reproduksi di Kelas XI IPA SMA Negeri 1 Percut Sei Tuan" bahwa hasil belajar siswa 
dengan menggunakan media audio-visual lebih efektif dari pada hasil belajar siswa yang menggunakan media sederhana.

\section{METODOLOGI PENELITIAN}

Jenis penelitian yang dilakukan dalam penelitian ini adalah quasi eksperimen. Penelitian ini akan dilaksanakan di sekolah SMA Negeri 5 Binjai yang beralamat di Jln. Jambi No.5 Rambung Barat Binjai. Dan jumlah seluruh populasi pada penelitian ini adalah 30 siswa, yaitu kelas XI IPA. Pada penelitian ini teknik pengambilan sampel yang digunakan adalah sampel total (Total Sampling). Sampel penelitian ini sebanyak 1 kelas. Kelas XI IPA-I sebagai kelas eksperimen yaitu kelas yang pembelajarannya menggunakan media animasi.

Pada prinsipnya metode analisis data lingkungan untuk mengolah data dengan menggunakn metode statistik yang dapat untuk mencari kesimpulan. Data yang diperoleh dalam penelitian ini terdiri dari hasil data berupa prestest, prosttes, dan Lembar Kerja Siswa. Pengolahan data dilakukan dengan membandingkan hasil analisis penguasaan tiap kategori konsep pada prestest dan hasil analisis pada posttes. Selain itu, setelah data diperoleh dari hasil penelitian, maka data tersebut diolah secara statistik.

\section{HASIL PENELITIAN}

Data yang diperoleh dalam penelitian ini terdiri atas dua jenis, pertama adalah data pretes yang digunakan untuk melihat perbandingan pengetahuan awal siswa mengenai materi pokok Sistem Reproduksi pada kedua kelas penelitian sebelum kedua kelas diberikan perlakuan dengan media pembelajaran yang berbeda. Kedua adalah data postes atau data hasil belajar siswa pada kedua kelas setelah diberikan perlakuan dengan menggunakan media pembelajaran yang berbeda.

Dari hasil pretes diketahui nilai ratarata siswa pada kelas media animasi sebesar 36,78 dengan simpangan baku (SD) sebesar 8,09 . Dari hasil postes diketahui nilai ratarata siswa pada kelas media animasi sebesar 79,56 dengan simpangan baku (SD) sebesar 7,46. Pengujian hipotesis dilakukan dengan menggunakan uji beda (uji-t). Uji-t dilakukan dengan membandingkan nilai rata-rata rata-rata postes dari kedua kelompok penelitian. Berdasarkan perhitungan yang telah dilakukan, diketahui nilai rata-rata postes kelas media gambar adalah sebesar 79,56 sedangkan nilai ratarata postes kelas media animasi adalah sebesar 69,33. Varians gabungan untuk kedua data postes tersebut adalah sebesar 7,30. Dengan menggunakan harga rata-rata dan varians gabungan dari kedua kelompok 
penelitian, diketahui harga $t_{\text {hitung }}$ yakni sebesar 5,72. Nilai $t_{\text {hitung }}$ yang diperoleh selanjutnya dibandingkan dengan nilai $t_{\text {tabel }}$ dengan dk (58) untuk $\alpha(0,05)=2,00$. Dari hasil perbandingan harga $t_{\text {hitung }}$ dengan $t_{\text {tabel }}$ diketahui bahwa $t_{\text {hitung }}>t_{\text {tabel }}(5,72>2,00)$. Dengan melihat hasil tersebut dapat disimpulkan bahwa dalam penelitian ini $\mathrm{H}_{\mathrm{a}}$ diterima sekaligus menolak $\mathrm{H}_{0}$ yang berarti terdapat Pengaruh Penggunaan Media Animasi Terhadap Hasil Belajar Biologi Siswa Pada Materi Pokok Sistem Reproduksi Pada Manusia Di Kelas XI IPA SMA Negeri 5 Binjai. Dari hasil pengujian hipotesis tersebut juga dapat disimpulkan bahwa pembelajaran yang dilakukan dengan menggunakan media animasi lebih efektif untuk meningkatkan hasil belajar siswa pada materi pokok sistem reproduksi.

\section{KESIMPULAN DAN SARAN}

\section{A. Kesimpulakn}

Adapun yang menjadi kesimpulan

dalam penelitian ini adalah :

Pengaruh Penggunaan Media Animasi Terhadap Hasil Belajar Biologi Siswa Pada Materi Pokok Sistem Reproduksi Pada Manusia Di Kelas XI IPA SMA Negeri 5 Binjai adalah sebesar 79,56 yang tergolong kategori baik.

\section{B. Saran}

Berdasarkan hasil penelitian ini, maka penulis menyarankan :

1. Bagi Guru biologi di SMA Negeri 5 Binjai agar mencoba menerapkan media animasi dan media gambar di dalam pembelajaran sistem reproduksi manusia dalam upaya meningkatkan pencapaian hasil belajar siswa.

2. Dalam pelaksanaan pembelajaran yang menggunakan media animasi dilakukan persiapan yang matang dalam penyediaan perangkat-perangkat media animasi beberapa hari sebelum proses pembelajaran berlangsung agar penggunaan waktu lebih efektif dan efisien.

3. Kepada siswa diharapkan untuk lebih giat dan aktif dalam pembelajaran, tidak takut dan malu bertanya kepada guru dan mengulang-ulang pelajaran di rumah serta disarankan sering menonton VCD pembelajaran tentang sistem reproduksi manusia yang sudah mulai banyak dijual untuk umum, agar lebih memahami materi pelajaran tersebut.

\section{DAFTAR PUSTAKA}

Anonim, (2009), Pedoman Penulisan Proposal Dan Skripsi Mahasiswa Program Studi Pendidikan, FMIPA Unimed 
Ariani, N., (2007), Pembelajaran Multimedia di Sekolah, Prestasi Pustaka, Jakarta.

Arikunto, S. 2007. Prosedur Penelitian, Rineka Cipta, Jakarta

Arsyad, A, (2009), Media Pembelajaran, Penerbit Pt. Raja Grafindo Persada, Jakarta.

Dahar, W.R., (2005), Teori-Teori Belajar, Penerbit Erlangga, Jakarta

Dimiyanti dan Mudjiono, (2002), Belajar dan Pembelajaran, Rineka Cipta, Jakarta.

Indrawati, (2006), Model Pembelajaran IPA, Departeman Pendidikan Nasional, Dirjen Pendidikan Dasar dan Menengah, Jakarta.

Janiansya, (2009), Pengertian Multimedia, http://wordpress.com/ diakses pada tanggal 15

Oktober 2019.

Laura, (2008), Efektivtas Penggunaan VCD Pembelajaran Terhadap Pencapaian Kompetensi Dasar Sub Materi Pokok Fertilisasi, Gestasi, dan Persalinan di Kelas XI IPA SMA NEGERI 2 Pemata ng Siantar T.P.2007/2008, Skripsi J urusan Biologi, FMIPA, UNIMED, Medan.

Mahir, I.,(2010), Efektifitas Media Pembelajaran Digital Video Disc (DVD) Dan Gaya Belajar Terhadap Pencapain Prestasi Belajar Siswa Tehnik Mesin, http://edu-articles.com/ diakses pada tanggal 26 Oktober 2019.

Marbun, M., (2010), Perbedaaan Hasil Belajar Siswa yang Menggunakan audio-visual dengan Media Sederhana pada Pokok Bahasan
Reproduksi Di Kelas XI SMA Negeri 1 Percut Sei Tuan, Skripsi Jurusan Biologi, FMIPA, UNIMED, Medan.

Prabowo, P, (2010), Perbedaan Hasil Belajar Biologi Menggunakan Media Peta Konsep Dan Media Audio-Visual Pada Materi Pokok Sistem Peredaran Darah Manusia di Kelas XI SMA N 2 Medan T.P. 2009 / 2010, Skripsi Jurusan Biologi, FMIPA, UNIMED, Medan.

Purnomo,W, (2008), Sistem Reproduksi manusia, Surabaya. http://www.esmartschool.com/pnu/00 4/PNU0040012.asp_(diakses 7 Oktober 2019).

Pratiwi, D., Sri Maryati., Srikini., Suharno., Bambang, S., (2007), IPA Biologi Smu Kelas XI, Erlangga, Jakarta.

Sagala, S., (2003), Konsep dan Makna Pembelajaran, Alfabeta, Bandung.

Santyasa, I., (2007), Landasan Konseptual Media Pembelajaran, http://wordpress.com/ diakses pada tanggal 2 Februari 2019.

Sudjana, (2002), Metoda Statistika, Tarsito, Bandung.

Warsita, B, (2008), Teknologi Pembelajaran, landasan dan aplikasinya, Rineka Cipta, Jakarta. 